\title{
MATHEMATICAL MODEL OF A REAL STIRLING ENGINE CALIBRATED BY EXPERIMENTS
}

\author{
JIŘí VÁVRA, LIBOR ČERVENKA, MICHAL TAKÁTS \\ ČVUT v Praze, Strojní fakulta, Centrum vozidel udržitelné mobility, Technická 4,166 07 Praha 6, \\ E-mail: jiri.vavra@fs.cvut.cz, libor.cervenka@fs.cvut.cz, michal.takats@fs.cvut.cz
}

\section{JOSEF BROŽ}

Strojírny Bohdalice a.s., Bohdalice 63, 68341 Bohdalice

E-mail: broz@strobo.cz

\section{SHRNUTÍ}

Článek se zaměřuje na popis termodynamiky reálného Stirlingova motoru pro stacionární výrobu elektrické energie a tepla z obnovitelných zdrojů. Byly zaznamenány úhlově indexované - v závislosti na natočení klikového hř́dele záznamy rychle proměnných tlaků ve studeném a horkém válci nad písty a v prostoru pod písty při různém zatí̌̌ení. Měření byla uskutečněna na vývojové zkušebně výrobce motorů. Tlakové průběhy byly analyzovány pomocí softwarových nástrojů vyvinutých na univerzitě. Článek dále popisuje nástroje pro analýzu experimentálních dat, které byly využity pro kalibraci detailního 1-D termodynamického modelu motoru vyvinutého na univerzitě s využitím komerční ho kódu GT-Power. Model bude využit pro optimalizace konstrukce motoru.

KLIĆCVÁ SLOVA: STIRLINGÜV MOTOR, TERMODYNAMICKÝ MODEL, KALIBRACE, MĚŘENÍ OKAMŽITÝCH TLAKŮ

\section{ABSTRACT}

The article presents a look into the thermodynamics of a real Stirling engine used as a stationary electric power source and for heat generation from a renewable energy source. Crank angle based measurements were recorded of fast changing pressures in a cold and hot cylinder above and below the piston at various load conditions. The experimental data have been acquired on a prototype engine in an engine manufacturer's laboratory. The acquired pressure records have been post-processed and analyzed by the software tools developed at the university. The experimental data analysis is discussed in the article. The experimental data have been used for calibration of a detailed 1-D thermodynamic model of the engine system. The model was developed using the commercial software code GT Power. Further design optimizations will be performed with the model.

KEYWORDS: STIRLING ENGINE, THERMODYNAMIC MODEL, CALIBRATION, INSTANTANEOUS PRESSURE MEASUREMENTS

\section{INTRODUCTION}

The main purpose of this study is an experimental and theoretical investigation of thermodynamics and acquisition of a set of calibration data for a 1-D detailed thermodynamic model [1] of a real Stirling engine. The validated thermodynamic model is applied for feasibility studies or as a design tool for parametric sensitivity analyses and design optimizations.

The field of application of Stirling engines can be broad. The main advantage of Stirling engines is their neutrality to heat source. For stationary applications, the Stirling engine can be used as CHP (Combined Heat and Power) generators utilizing a wide range of heat sources from a broad scale of fossil or renewable sources including concentrated solar power.

According to [2], [3] the thermal efficiency of real (small scale - less than 10kWe) Stirling engine CHP is lower than for an internal combustion engine of comparable power output. One of the goals of the ongoing R\&D work is a detailed investigation of working cycle and characterization of losses using a combination of the experiments with advanced thermodynamic analysis software [4] and utilization of a commercial 1-D thermodynamic simulation tool for improving performance of the current system. 


\section{EXPERIMENTAL EQUIPMENT}

\subsection{ENGINE DESCRIPTION}

The Stirling a-type engine schematic is displayed in Figure 1 on the left alongside a picture of the real test prototype on the right. Pressurized helium is reciprocally moved by the phased pistons between hot (expansion) cylinder and cold (compression) cylinder via a heater, regenerator and a cooler. The displacement of each cylinder is $183 \mathrm{~cm}^{3}$. Cooler wall temperature was controlled at $60^{\circ} \mathrm{C}$ and heater wall temperature is controlled at $650^{\circ} \mathrm{C}$. The regenerator is made from sintered stainless steel mesh.

Actual displacements of the two pistons in the hot (red line) and cold (blue dotted line) cylinders are plotted in Figure 2. The grey area between the lines represents total working medium displacement of the whole engine.

The space under the pistons on both the hot and cold sides is interconnected with a buffer space. The buffer space is connected with the space above the compression piston by small orifices (not displayed in the figure). The buffer space is a practical means of smoothing the engine operation. It also helps to unload the most stressed components, such as the piston, rings and entire cranktrain. For laboratory tests the engine was fed by heat delivered from a natural gas fueled burner. The engine is coupled to a three-phase asynchronous generator connected

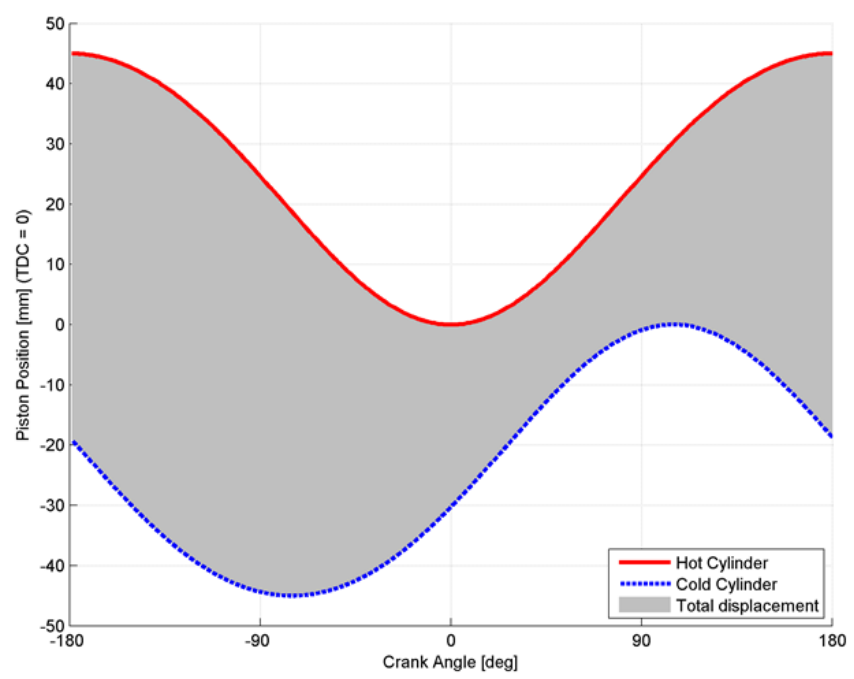

FIGURE 2: Strokes of the hot and cold pistons together with the total working stroke of the whole engine OBRÁZEK 2: Zdvihy horkého a studeného pístu spolu s celkovým pracovním zdvihem celého motoru

to the electric grid for either loading or motoring (starting) the engine. An engine speed close to $1500 \mathrm{rpm}$ was maintained by the electric grid for all operating conditions.
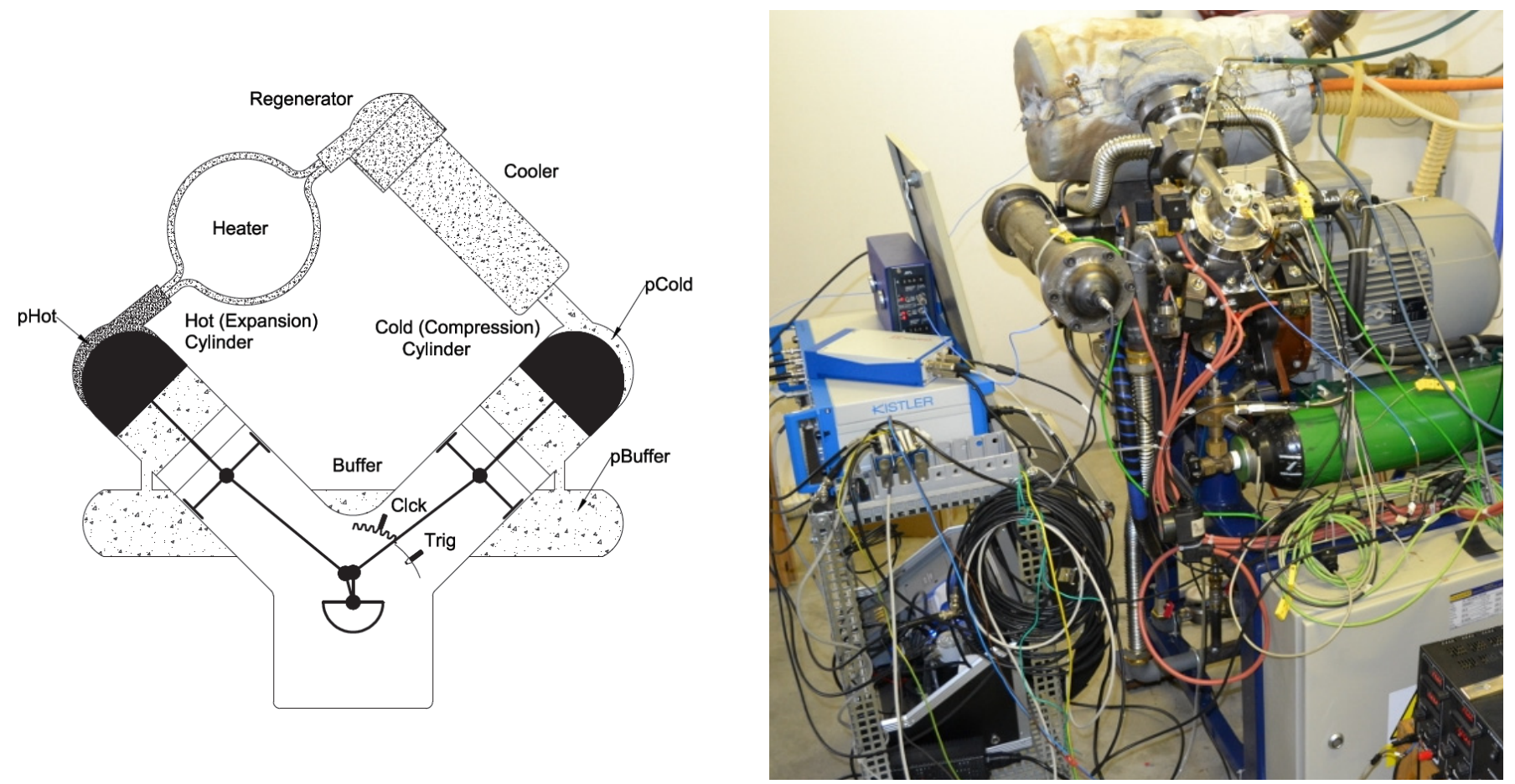

FIGURE 1: Stirling engine schematic (left) and real test engine (right) OBRÁZEK 1: Schéma Stirlingova motoru (vlevo) zkoušený prototyp (vpravo) 
Main engine parameters are shown in Table 1.

TABLE 1: Main engine and generator data

TABULKA 1: Hlavní parametry motoru a generátoru

\begin{tabular}{|c|c|}
\hline \multicolumn{2}{|c|}{ Basic Engine Data } \\
\hline Configuration & V - 2, $\alpha-$ type Stirling \\
\hline Bore/Stroke $(\mathrm{mm})$ & $72 / 45$ \\
\hline Con Rod Length (mm) & 120 \\
\hline Working Gas & $\mathrm{He}$ \\
\hline Average Gas Pressure & $4,6,8,10$ and $12 \mathrm{MPa}$ \\
\hline Engine Speed & $\sim 1500 \mathrm{rpm}$ \\
\hline Fuel & Natural Gas \\
\hline Generator & AC Asynchronous \\
\hline
\end{tabular}

\subsection{MEASUREMENT SETUP}

All measurements were performed at the engine manufacturer's development facility. The test cell is equipped with a low speed data acquisition system, which is a part of the engine control system. The system records average temperatures of the working gas in all spaces of the engine, coolant and lube oil temperature, average pressure in the buffer space and maximum pressure in the cold cylinder, electric power and fuel consumption.

Three fast changing pressures in the spaces of the Stirling engine were sensed using AVL GU21D uncooled piezoelectric pressure transducers. The first pressure transducer was mounted in a water-cooled adapter in the head of the expansion cylinder, the second one in the head of the compression cylinder and the third one in the buffer space (see symbols $p_{\text {Hot' }}, p_{\text {Cold }}$ and $p_{\text {Buffer }}$ in Figure 1).

The first two pressure sensors were connected to the two channel type 5064 Kistler charge amplifier installed in a 2853A Kistler SCP (Signal Conditioning Platform). The third one was connected to the AVL charge amplifier. The charge amplifier output voltage was digitized using a National Instruments CDAQ-9188 Ethernet data acquisition chassis with two NI 9222 analogue input modules (500 kHz simultaneous sampling, 4 channels).

Additional analogue inputs were dedicated for the recording of voltage signals from two proximity sensors sensing a timing mark and teeth on a flywheel gear ring. The first one generating a single pulse per revolution (for identification of the crank shaft angle position of the record) and the second one generating 124 pulses per revolution for identification of the instantaneous crank shaft angular position (see Trig and Clck signals in Figure 1).

All measurements were taken at a steady state with a sufficient time for thermal stabilization after a change in regime. All measured channels were sampled simultaneously with a sampling frequency of $50 \mathrm{kHz}$. For each measured regime a two-second record with 100k samples was recorded and stored on a PC hard drive as a text file.

\subsection{DATA PROCESSING PROCEDURE}

As a first post-processing procedure the time based records of fast changing quantities were resampled into the crank angle indexed records. An angle resolution of $0.29032{ }^{\circ} \mathrm{CA}$ (1240 samples per revolution $=1 / 10$ of the angle between two consecutive teeth on a flywheel gear ring) was used for all data processing procedures. The record was trimmed to begin with the first occurrence of the trigger mark at the sensor.

Although the stationary position of the trigger mark related to the piston top dead center position was known, it was necessary to find an actual "dynamic" TDC position for determination of the volume above the pistons for calculations of mean effective pressures (see below). A direct TDC measurement using a standard TDC sensor was not possible because none of the commercially available TDC sensors ensure gas tightness. This is not an issue in the case of a motored internal combustion engine filled with air, but in the case of a Stirling engine, continuous helium leakage is not acceptable. A stationary TDC position was therefore used solely in the first iteration of the following procedures.

\subsubsection{TDC DETERMINATION PROCEDURE}

A mean indicated pressure was evaluated for each cylinder separately by means of the following equation:

2 IMEP $_{\text {in }}=\frac{\int_{-360^{\circ}}^{360^{\circ}}\left(p_{C Y L}-p_{\text {BUFF }}\right) d x}{x}$.

This relationship is equivalent to the formula valid for a fourstroke engine. The four-stroke engine calculation procedure was chosen because it was the only option available in the software tool used for evaluation. Symbol $x$ characterizes a piston distance from its TDC position.

The engine was tested in a set with an asynchronous generator, the effective torque $M_{t}$ was therefore calculated according to

$$
M_{t}=\frac{P_{G E N}}{0.00105 \times n \times \eta_{G E N}},
$$

where $P_{G E N}$ is an effective electric power output of the generator (in units of $\mathrm{kW}$ ) and $h_{\text {GEN }}$ is generator efficiency and $n$ is its rotational speed in rpm.

The brake mean effective pressure of the whole engine was calculated as 
$2 B M E P=\frac{4 \pi}{V_{Z}} M_{t}$

The last expression also uses four-stroke engine convention assuming cylinder displacement $\left(V_{z}\right)$ of one cylinder.

The mean indicated pressure of the whole engine is then calculated by means of

$2 I M E P_{\text {out }}=\frac{2 B M E P}{\eta_{M E C H}}$

The outputs from the relationships (1) to (4) were used for determination of the TDC (Top Dead Center) position of crank angle indexed pressure records. When determining the TDC it was assumed that the difference between absolute values of mean indicated pressures of both cylinders from equation (1) should be equal to the result of equation (4).

$$
I M E P_{\text {in }}=I M E P_{\text {out }}
$$

The whole procedure is illustrated in Figure 3 for two regimes (low load on the left and high load on the right). Equation (1) was gradually calculated in the vicinity of the initial TDC position estimate for a compression cylinder (2IMEPC - crosses, negative values) and the expansion cylinder (2IMEPH - red squares, positive values). The sum of the values gives an engine total mean effective pressure 2IMEP (circles), and the correct value of the TDC should be equal to the value of 2IMEPout calculated using equation (4). Crank shaft position in degrees is used on the horizontal axis.
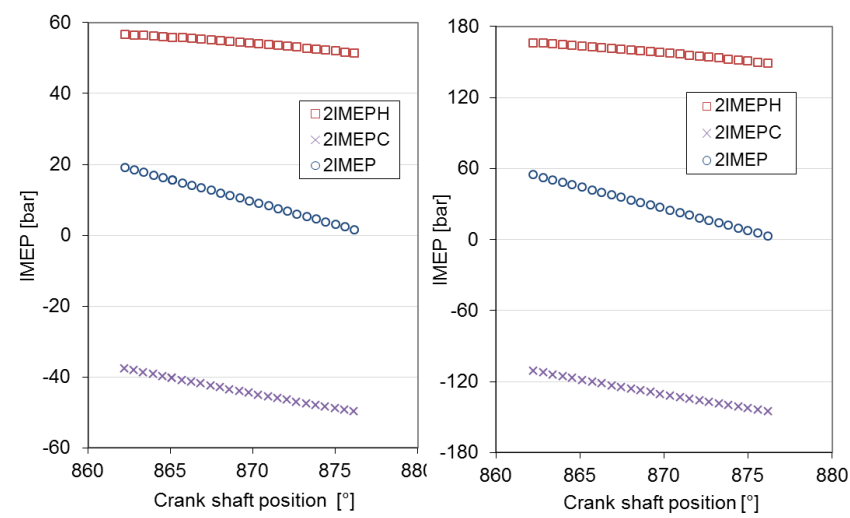

FIGURE 3: Example of TDC position determination at low engine load on the left and at high load on the right

OBRÁZEK 3: Příklad stanovení polohy horní úvratě při nízkém zatížení vlevo a ve vysokém zatížení motoru vpravo
Figure 4 plots the mean indicated pressure traces evaluated from indicated pressures for several operation regimes with various mean buffer pressures. Horizontal dashed lines represent values of 2IMEPout for corresponding regimes calculated from the power output of the generator assuming constant mechanical losses of $2 \mathrm{~kW}$ as had been initially estimated with a free deceleration test. The horizontal position of the cross-section of uniform colored curves determines the TDC position in the record (an index from the start of the record).

It is obvious that such a determination of TDC is indefinite. The figure plots the results of the sensitivity analysis for values of mechanical losses of 1.7 and $1.0 \mathrm{~kW}$. There might be several reasons for this disproportion:

- Variable absolute value of mechanical losses

- Variable efficiency of the generator due to oscillations of instantaneous angular speed

The TDC position value of 2970 was selected and kept constant for the subsequent evaluations. Furthermore, an additional cross-check of the TDC position using the comparison of directly measured and calculated instantaneous crank shaft speed is possible.

\subsubsection{DETERMINATION OF ABSOLUTE PRESSURES}

The measurement chain with a piezoelectric pressure sensor and a charge amplifier only operates with the $\mathrm{AC}$ component of the signal. The absolute value "zero position" must therefore be determined in a different way.

A compression cylinder head was equipped with an absolute pressure transducer with a peak pressure holder so that it was possible to peg the instantaneous pressure to this maximum value. Measured pressure traces in the expansion cylinder were symmetrically centered to the average value of the previously pegged pressure in the compression cylinder as displayed in Figure 5.

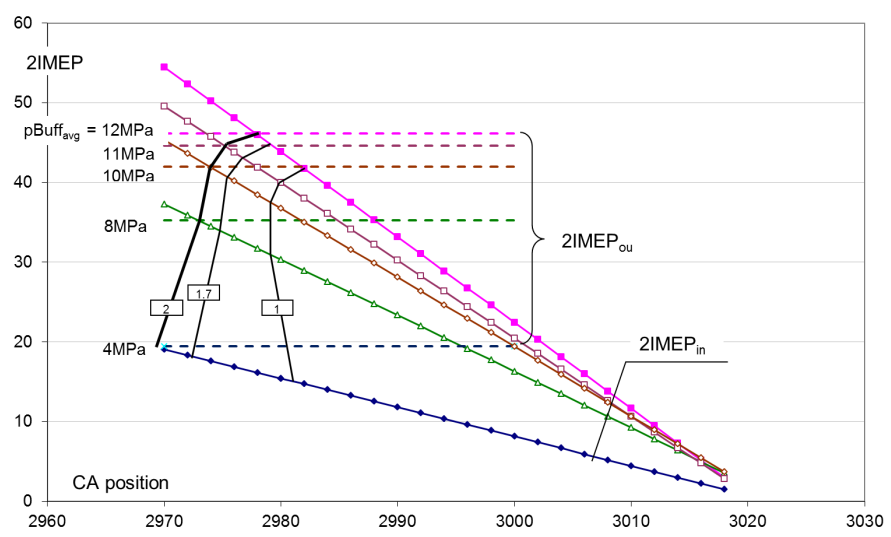

FIGURE 4: Result of the TDC position determination at various engine loads

OBRÁZEK 4: Výsledek určení polohy horní úvratě při různých zatížení motoru 


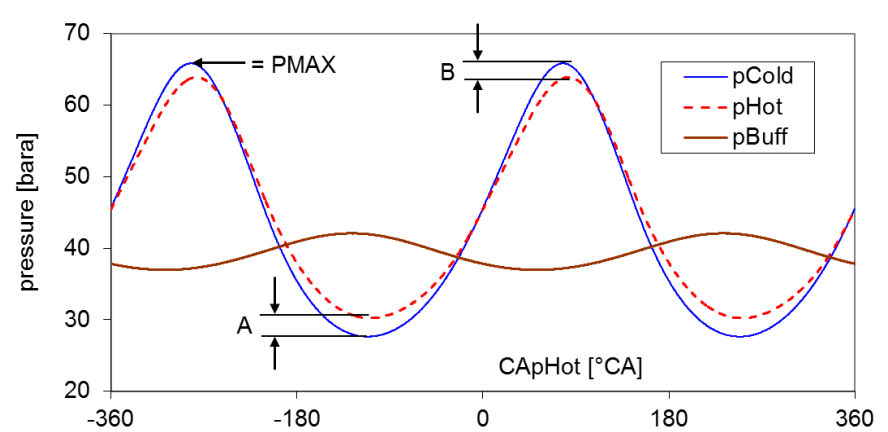

FIGURE 5: Pegging of the measured instantaneous pressures in the engine working spaces

OBRÁZEK 5: Posun absolutních hodnot okamžitých tlaků v pracovních prostorách motoru

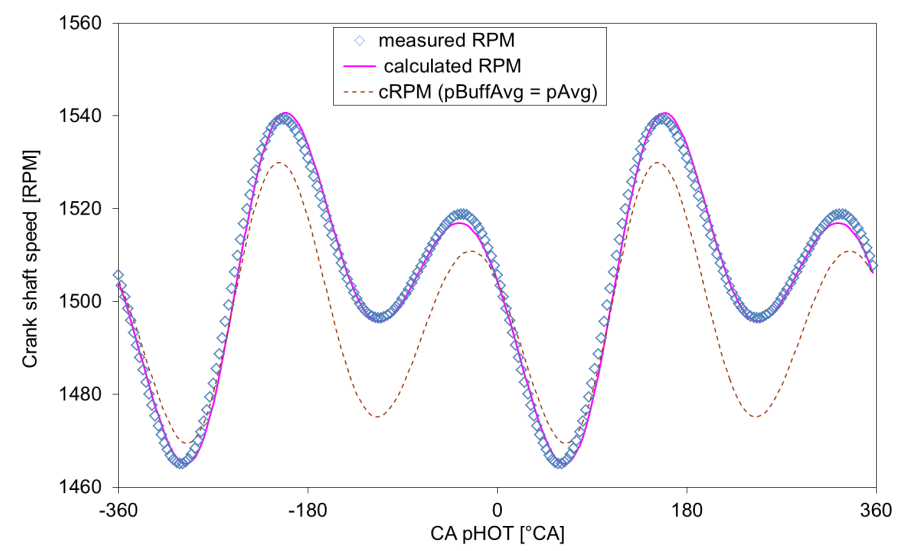

FIGURE 6: Validation of pegging of the instantaneous pressure in the buffer by comparing measured and calculated instantaneous crankshaft speed traces

OBRÁZEK 6: Kontrola posunutí absolutních hodnot okamžitých tlaků v prostoru bufferu porovnáním změřené a vypočtené okamžité úhlové rychlosti klikového hř́dele.

A comparison of directly measured and calculated traces of the instantaneous crankshaft speed was performed as the best criterion for determination/evaluation of correctness of the pegging of the pressure in the buffer. The buffer pressure was shifted gradually and the impact on the course of the instantaneous rotational speed was observed visually.

The resulting match of the $\mathrm{c}_{\mathrm{RPM}}$ (calculated RPM) curve to the measured instantaneous crankshaft speed, marked $m_{\text {RPM }}$ (measured RPM), is presented in Figure 6. The $m_{\text {RPM }}$ curve was smoothed by the FFT and inverse FFT using five main harmonic components of the signal for decomposition. The dashed curve represents the calculated instantaneous speed with an average buffer pressure pegged to the measured one by the slow response absolute pressure transducer used by the LS data acquisition system.
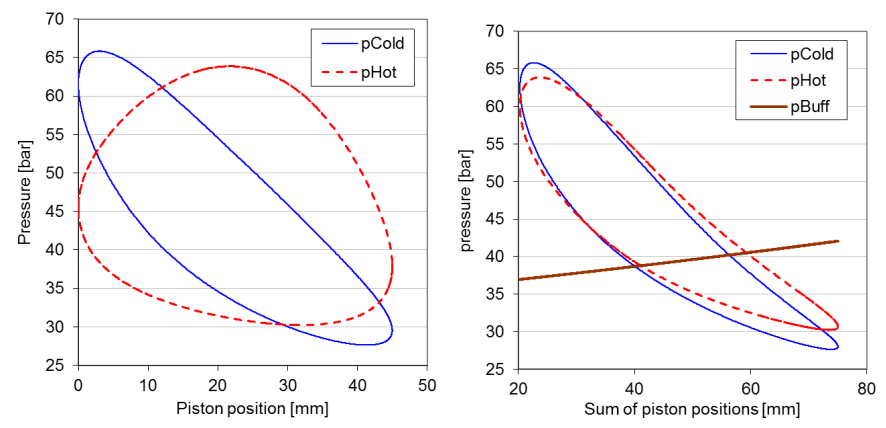

FIGURE 7: Pressure traces in both cylinders at low engine load plotted over corresponding piston positions (left) and over the sum of both piston positions with the pressure trace in the buffer (right) OBRÁZEK 7: Průběhy tlaků v obou válcích při nízkém zatížení v závislosti na poloze pístů od HÚ (vlevo) a v závislosti na součtu poloh obou pístů společně s průběhem tlaku ve vyrovnávacím prostoru (bufferu) (vpravo)
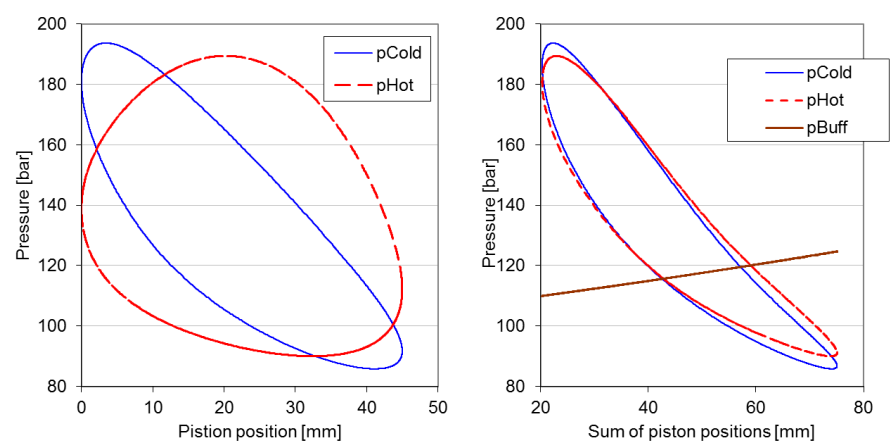

FIGURE 8: Pressure traces in both cylinders at high engine load plotted over corresponding piston positions (left) and over the sum of both piston positions with the pressure trace in the buffer (right) OBRÁZEK 8: Průběhy tlaků v obou válcích príi vysokém zatižení v závislosti na poloze jednotlivých pístů (vlevo) a v závislosti na součtu poloh obou pístů společně s průběhem tlaku ve vyrovnávacím prostoru (bufferu) (vpravo)

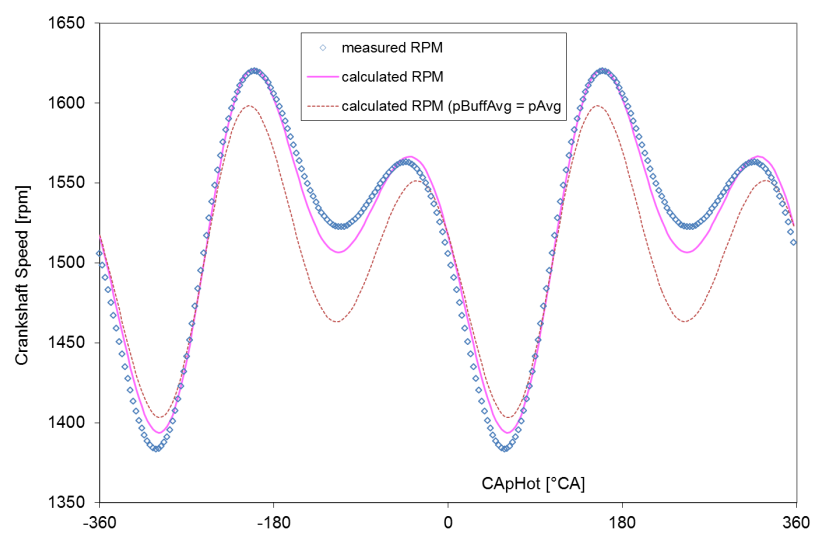

FIGURE 9: Measured and calculated instantaneous crankshaft speed of the engine at high power output

OBRÁZEK 9: Změřené a vypočítané průběhy okamžitých otáček klikového hř́dele motoru při vysokém zatižení 
The instantaneous crankshaft speed curve was determined by the pressure traces as an input value and the mass of the piston, piston and connecting rods and reduced moment of inertia of rotating parts of the engine (crankshaft, flywheel).

\section{EXPERIMENTAL RESULTS}

Figure 5 displays an example of the plotted pressure traces in both cylinders.

Figure 6 represents an example of evaluation of the engine running roughness. The independent variable for both figures is the crank angle position of the expansion cylinder. Both of the figures show the experimental data acquired in one regime at low engine power output.

Figure 7 and Figure 8 show another method of plotting the pressure traces. The left picture displays pressure traces plotted over individual positions of the pistons. On the right the same traces are plotted over the sum of both pistons positions. Figure 9 displays the match of calculated and measured curves of the instantaneous crankshaft speed for the high power output regime.

\section{GT-POWER ENGINE MODEL}

The Stirling engine thermodynamic model was developed in commercial software package GT-Power, which enables a modular model design with many flexible elements contained in the software library. The simulation tool was originally focused on a single-acting reciprocating internal combustion engine. The model was computed with 1-D non-stationary processes in the pipes and 0-D processes in the elements representing volume changing (cylinder, compressor, turbine...). Processes computed in the 0-D depend only on time while processes computed in 1-D parts depend on the dimensions, in particular the length of the pipe and time. Gas dynamics equations for compressible fluid, the laws of conservation of mass, energy and momentum are used to solve the wave processes in the pipe. The model takes into account pipe heat transfer to the walls.

Figure 10 shows the engine model composed of GT-Power components. Hot_cyl and Cold_cyl represent the workspaces of the hot and cold cylinders. A heater, regenerator and a cooler are connected with the pipes and volume objects "fsx- $x$ ". The cylinders are linked to the icon "Engine" which represents

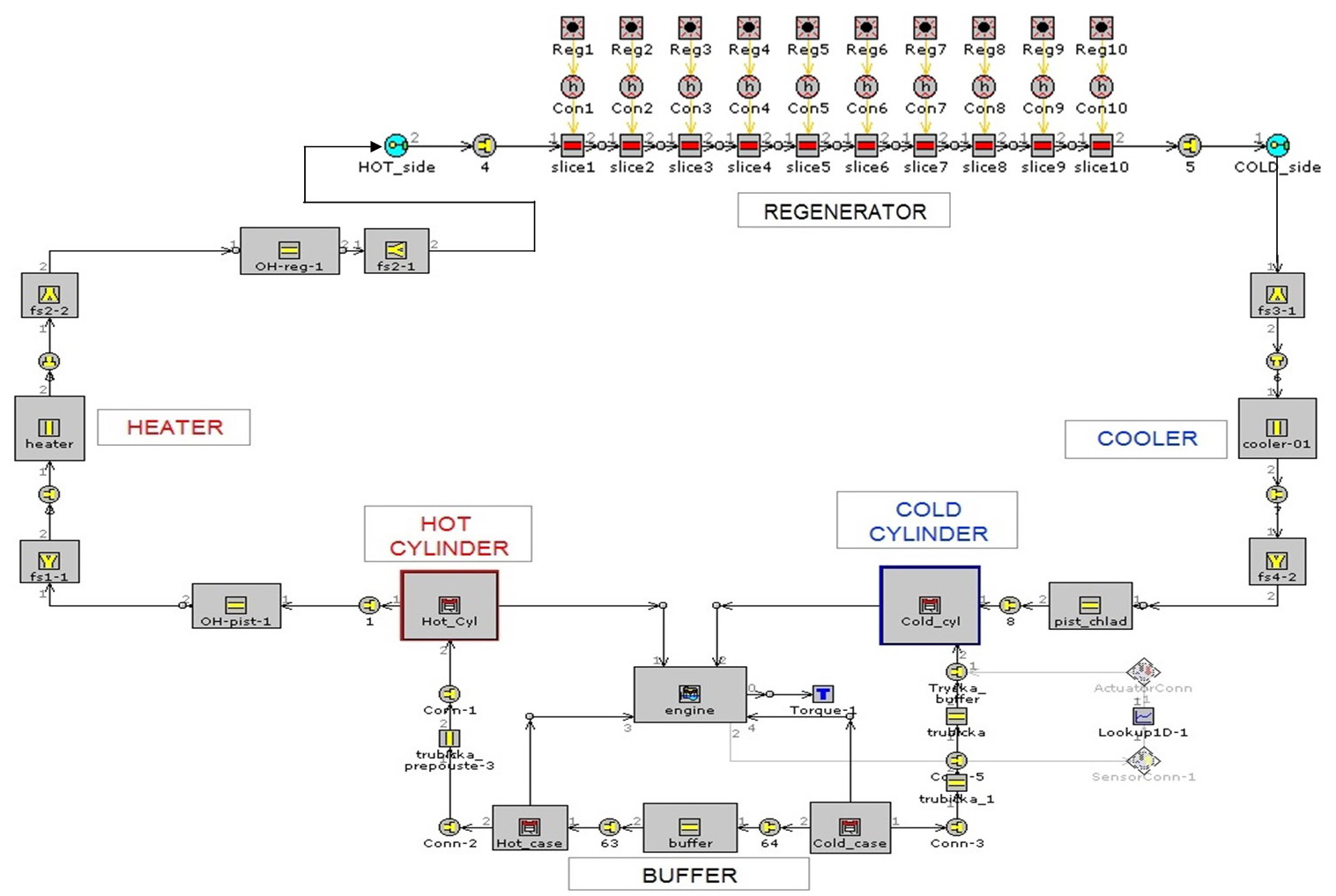

FIGURE 10: GT-Power model of a Stirling engine

OBRÁZEK 10: Model Stirlingova motoru v prostředí GT Power 
a crank mechanism. The crank mechanism is also linked to objects representing the crankcase "EngCrankCase" to which is attached an expansion tank "buffer" and a link to the cold cylinder workspace through the nozzle. The individual components are defined by the relevant parameters for the elements (e.g. dimensions, surface areas, bore and stroke of the cylinders, wall temperature, etc.).

The model of the regenerator is shown in Figure 11. This model is divided into 10 identical components. Here are defined dimensions and geometry parameters - "slice", thermal properties - "Con" and material properties - "Regen". The pressure loss coefficient of this model was tuned on a separate model to match the experimental data measured on a steady flow test rig.

\subsection{GT-POWER ENGINE MODEL CALIBRATION}

The model was calibrated to match the instantaneous pressures measured in the cold and hot cylinder and the pressure in a buffer at various load conditions. The load was set by changing the mean buffer pressure of $40,60,80,100$ and 120 bar. In the model the mean buffer pressure is set by the value of the initial pressure (i.e. on the working fluid mass at the beginning of the simulation). After the calibration only initial pressure was changed in the final model whilst keeping all the other model parameters constant. The results of this process are shown by the comparison of measured and calculated pressures in Figure 12.

Unbroken lines represent measured traces and dashed lines computed ones. The figures show comparisons between measured and calculated values. Calculated buffer pressure exhibits a systematic positive offset to the measured one. This difference is thought to be an error caused by the incorrect

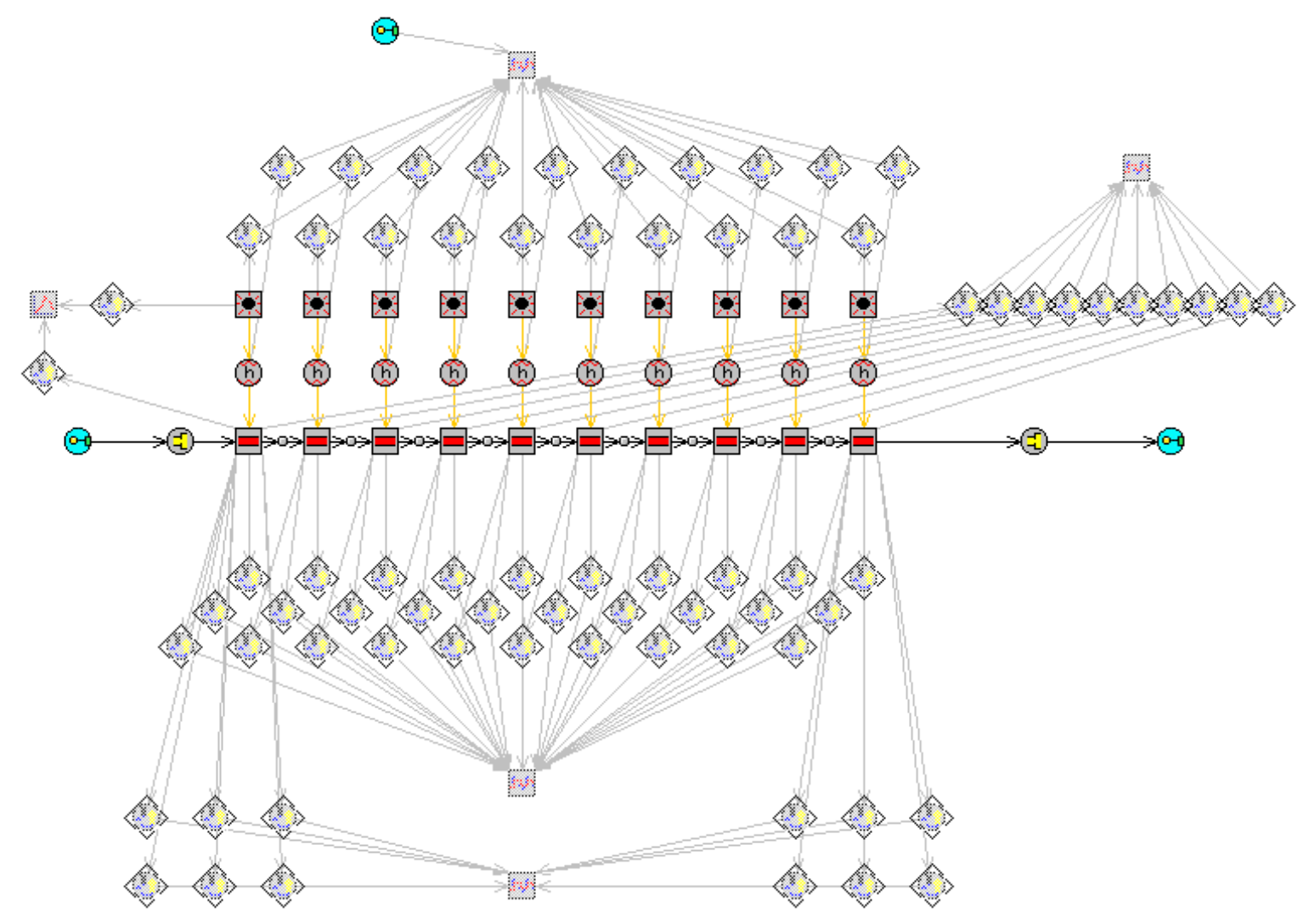

FIGURE 11: GT-Power model of the Stirling engine regenerator

OBRÁZEK 11: Model regenerátoru Stirlingova motoru v prostředí GT Power 

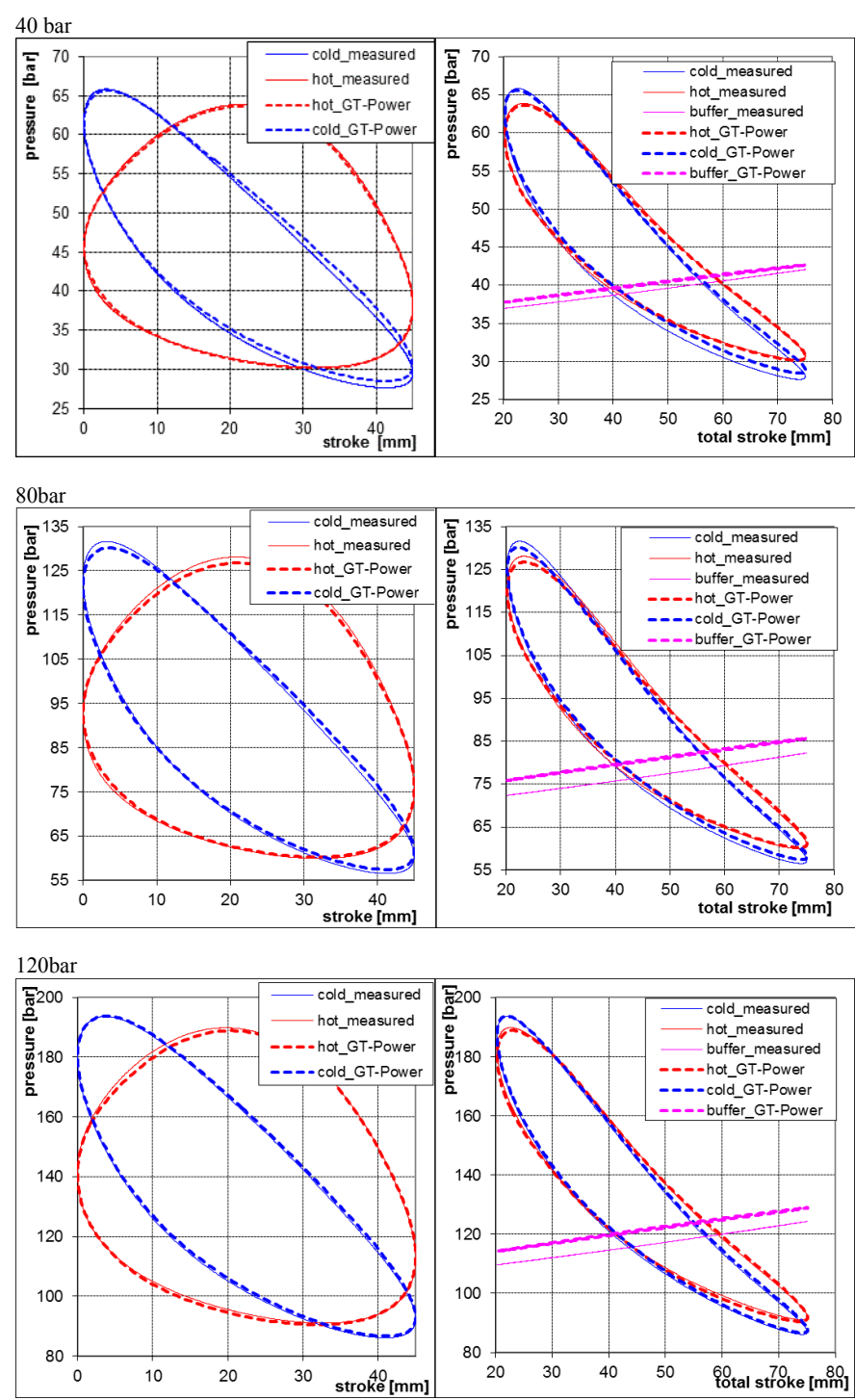

FIGURE 12: Pressure-stroke diagrams in a hot and cold cylinder (left) pressure-total stroke diagrams for various buffer mean pressures (right) OBRÁZEK 12: Závislost tlaku v horkém a studeném válci na zdvizích pístů (vlevo) pro různé střední tlaky ve vyrovnávacím prostoru (bufferu), závislost tlaků na celkovém zdvihu-objemu nad oběma písty (vpravo)

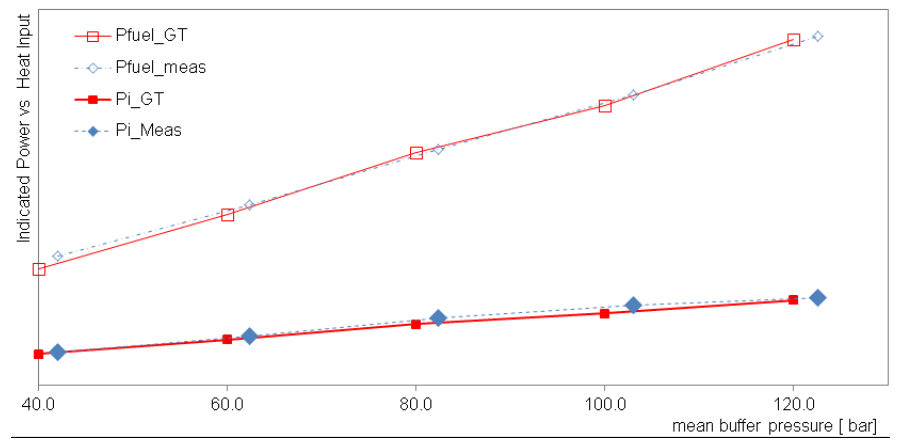

FIGURE 13: Modeled and measured traces of heat input and indicated power after calibration in relation to buffer mean pressure OBRÁZEK 13: Modelované a změřené průběhy přivedeného tepla a indikovaného výkonu v závislosti na středním tlaku ve vyrovnávacím prostoru (bufferu) shift of the measured buffer pressure. Measurements of the instantaneous buffer pressure using a piezoresistive absolute pressure transducer are being prepared in the near future and will help to solve this uncertainty.

\section{RESULTS}

Figure 13 displays heat input and indicated power output in relation to buffer mean pressure. Increasing the buffer mean pressure increases the amount of working medium. Because the heater wall temperature is kept constant in the model as it is in reality, the heat transfer to the working medium is increased and engine power consequently increases. With a greater amount of working medium the velocity and pressure loss in the regenerator, cooler and heater increase, therefore the indicated efficiency falls and the slopes of heat input and indicated power lines diverge.

\section{CONCLUSIONS}

To the best of our knowledge this is the first time that real Stirling engine measurements of the instantaneous pressure traces in engine spaces have been published. Quite conventional testing HW commonly used for measurements in the field of internal combustion engines was used. On the other hand, several "unconventional" approaches were applied for the analysis of experimental data. A set of calibration data was generated enabling further progress in the simulation effort.

\section{NEXT STEPS}

Simulation optimizations are going on at the present time [1]. This contribution describes only a segment of data which had been used for the model calibration. Further improvement in testing equipment and methods is in progress. In subsequent experiments an absolute piezoresistive pressure transducer will be used instead of the piezoelectric one, which senses only relative values, for sensing instantaneous pressure in the buffer. At the same time a direct TDC position measurement is under preparation. Both of these upgrades should improve the plausibility of the measurements and should enable a deeper insight into the investigated subject.

\section{ACKNOWLEDGEMENTS}

This research has been realized using the support of EU Regional Development Fund in OP R\&D for Innovations (OP VaVpl) and Ministry for Education, Czech Republic, project \#CZ.1.05/2.1.00/03.0125 Acquisition of Technology for Vehicle Center of Sustainable Mobility. 
This work was partly supported by the Grant Agency of the Czech Technical University in Prague, grant No. SGS13/184/ OHK2/3T/12.

This support is gratefully acknowledged.

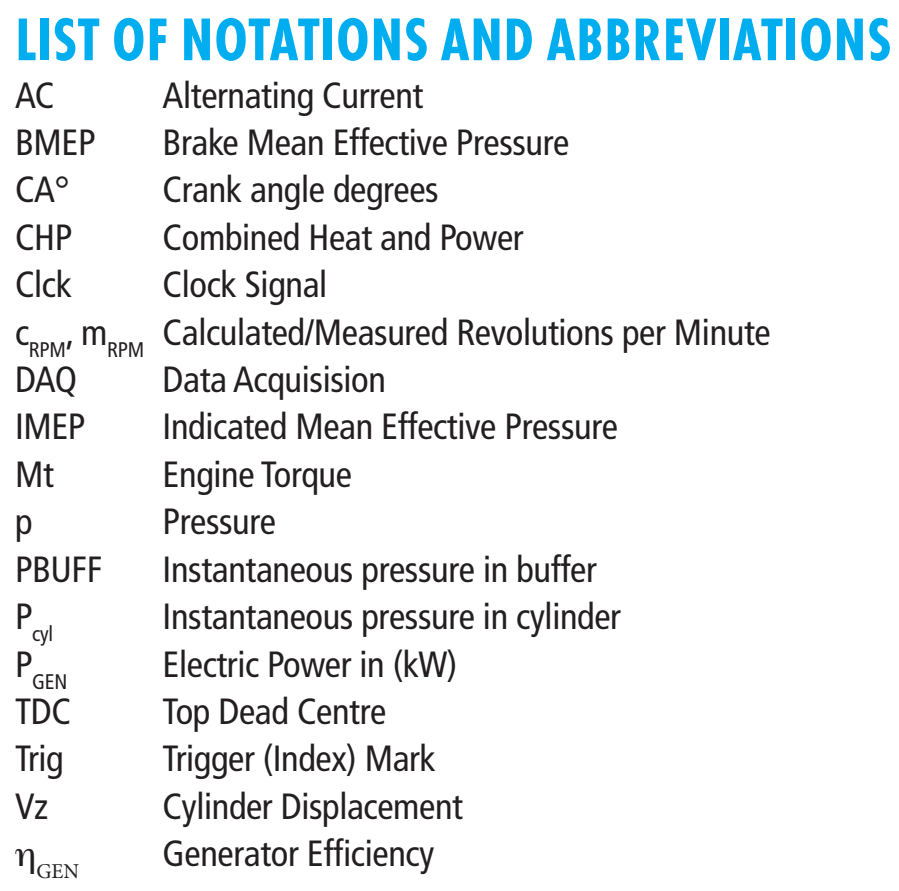

\section{REFERENCES}

[1] Červenka L., Mathematical Model of Real Stirling Engine, In Proceedings of XLIV. International Scientific Conference of the Czech and Slovak University Departments and institutions dealing with the Research of Internal Combustion Engines, Brno, Czech Republic, 2013

[2] E.D. Rogdakis, G.D. Antonakos, I.P. Koronaki, Thermodynamic analysis and experimental investigation of a Solo V161 Stirling cogeneration unit, Energy, Volume 45, Issue 1, September 2012, Pages 503-511, ISSN 0360-5442

[3] http://dx.doi.org/10.1016/j.energy.2012.03.012.

[4] ORGAN A. J. Thermodynamics and Gas Dynamics of the Stirling Cycle Machine. First published, Cambridge, Cambridge University Press, 1992. $415 \mathrm{~s}$.

ISBN 0-521-41363-X

[5] Takáts M., Vávra J., SW Tool for Generation of Angle Resolved Record of Fast Changing Physical Quantities, In Proceedings of XLIV. International Scientific Conference of the Czech and Slovak University Departments and institutions dealing with the Research of Internal Combustion Engines, Brno, Czech Republic, 2013 